\title{
FOLLOWING THE NON-MONEY TRAIL: RECONCILING SOME ANGKORIAN TEMPLE ACCOUNTS
}

\author{
Terry Lustig $^{1} \&$ Eileen Lustig ${ }^{1}$
}

\author{
${ }^{1}$ Affiliates University of Sydney, Department of Archaeology, \\ terry@environmentalmanagement.com.au\& eileen@environmentalmanagement.com.au
}

\begin{abstract}
Few Angkorian temple inscriptions contain data on revenues and scheduling of resources in a form that is both comprehensive and coherent. As a result, the operations of Angkor's temples and āśrama are not well understood. Yet to ensure sustainability, it must have been important for foundations to keep records, particularly of offerings to deities and maintenance of personnel, at times numbering into the thousands. This paper uses an accounting approach to shed some light on the modes of support for workers of religious establishments. Prime uncertainties addressed in the process are varying scales of weights and measures for rice, and volumetric relationships between different forms of rice. Working back from stated quantities of rice and paddy, at times unrealistically precise, we deduce that the auditors adopted a ratio of 2 when calculating the conversion of paddy to rice, rather than the 2.5 commonly used in contemporary Indian texts. We also reevaluate the frequencies of two religious festivals, sankkrānta and tithiviśeșana, and the meaning of vroh. The metabolic requirements of different age groups and sexes in rice-eating communities, together with the rations prescribed in some of Yaśovarman's āsrama allow us to estimate that a lih of rice at that time weighed between $800 \mathrm{~g}$ and $900 \mathrm{~g}$ and from this to infer the age range for boys who were studying in those āśrama. The implications of the profiting of some and the underprovisioning for other sanctuary personnel are considered in conjunction with the institution of fortnightly scheduling seen in some religious establishments.
\end{abstract}

\section{INTRODUCTION}

The inscriptions of Angkorian temples - our primary historical texts for the $9^{\text {th }}$ to the early $15^{\text {th }}$ centuries - are rarely explicit about the resources needed for their operation and maintenance. Where endowed allocations are recorded, they normally state a daily, annual or festival provision of food to the foundation deities. This was mostly rice, which today constitutes 80 percent of the Cambodian diet (Murshid 1998: 16). Some texts mention the maintenance of temple staff. These were the personnel, from the khñum vrah (slaves of the god), who fed, dressed, bathed, and entertained the deities, to the clerics conducting the rituals. We are told very little about them, other than perhaps their names in sometimes-long lists, their categories in order of status, their dependent children and perhaps their village (Lustig and Lustig 2013). Support was always in kind, since Angkor's society did not use money (Wicks 1992: 183-218, Lustig 2009). Only a few inscriptions tell us how much rice was allocated, how often, and to how many people. A handful $-\mathrm{K}$. numbers 56 (CE 878-977), 254 (CE 1129), 273 (CE 1186), 279, 290, 701 (all CE 889-915), 908 (CE 1191) and 989 $(\mathrm{CE} 1008)^{1}$ — set out the allowances for both deities and personnel in some detail, with only two of these (K. 989 and K. 254) having information sufficient for accounting analysis. Although the lower-status field workers, the khñum (slaves or bondsmen) or 'nak (people), appear in equally long lists, provision for them is not specified.

An initial investigation - seeking answers to the broad question of how the temples and their personnel were maintained - revealed ambiguities, anomalies and lacunae, similar to those encountered by other researchers (Cœdès 1951: 181, n. 4; Sedov 1963; Soutif 2009: 136153). There seemed to be instances of incredible precision juxtaposed with careless arithmetic, which was often difficult to follow. In accounting terms, the books didn't seem to balance. Such accounting appeared to contrast appreciably with the apparent accuracy in weighing precious metals to a fraction of a gram (Soutif 2009: 152) and the precision of calculations in Khmer contemporary astronomy (Eade 1995: 94).

The founders, their families and their appointees should have had good reasons to keep proper records on the operation of their religious establishments, to help them manage the resources derived from the lands and villages they had assigned to their foundations, and the labour of the attached workers (Thion 1993: 98). Where temple lands were free of levies, the founders might wish

1 All inscriptions we refer to are listed in Supplementary File 1, together with their dates and sources. The lines and inscription faces in Khmer texts, or the stanzas in Sanskrit texts are given in the paper, together with $\mathrm{CE}$ dates, where mentioned the first time, or where the dates are relevant to the discussion. 
to know the amount of tax-free surpluses produced. ${ }^{2}$ As well, where the superior was required to promote the enrichment of the establishment, as in the texts of three of Yaśovarman's (CE 889-915) āśrama (K. Nos. 701: LIII, 279: LII, 290: XLIX), proper accounts would have been vital, given too that, as we show in these and other temples and áśrama, elites were well provided for and could accumulate wealth. ${ }^{3}$

It is possible that detailed and accurate temple accounts are rare because they had been kept elsewhere on perishable materials. Yet this begs the question of why one would record partial or inaccurate information in a very permanent manner - on stone - and leads us to a broader question: can such records, even if imprecise, tell us something of the allocation of temple resources and the organisation and conditions of temple workers?

\section{THE ENDOWMENTS: PROVISION FOR THE FOUNDATIONS}

The deities had the highest priority. Some texts mention only annual or daily amounts or quantities for auspicious days and holidays. In many cases, the endowment provided only rice. For example, K. 33 (CE 1017: 29) tells us that a number of servants who were named "were ordered to provide $1 \frac{1}{2}$ je of milled rice for each fortnight at the full moon [and] new moon." 4 Other inscriptions specify a variety of offerings for the gods, including fruits.

For the sacrifice to the god: 2 lih of fruits. For the Five Sacrifices: 1 'var of unhusked grain, 1 'var of fried rice, 1 'var of barley, 1 'var of $\square$ व; 1 'var of beans, 1 $j e$ in the New Year (saíkrānta): 1 je.

$$
\text { K. } 88 \text { (CE 1003: 8-10) }
$$

Sanctuary workers are frequently recorded as part of the foundation's property or as having been donated as a 'meritorious gift', along with the cattle and the ricefields providing for the god.

Slaves of the god for the clear fortnight: [17 adults \& 8 children] $\circ$ Slaves of the god for the dark fortnight: [21 adults \& 7 children]. One hundred head of cattle, twenty buffaloes. $\bigcirc$ The ricefield from where they make the [cooked] rice for the god, (situated) to the] east and southeast of the reservoir, extending to the river, the ricefield Chok Phlvas, the ricefield from which [they] make the paddy for the allowance to the

2 We cannot be sure if all temples were exempt from state and local impositions, as immunities are mentioned only sometimes. It is possible that many, if not all, of those that were exempt had been offered to the king as "royal foundations" (Dominique Soutif, pers. comm. 2015).

3 This must have been a strong inducement for so many private foundations to be set up and explains the disputes over land and genealogy in numerous inscriptions of the $10^{\text {th }}$ and $11^{\text {th }}$ centuries (Vickery 1985).

4 English translations of the quotations in this paper are by the authors, adapted from the original French translations. kamraten jagat at Lingapura, the ricefield Sarāḥ.

K. 350 (CE 978-1077: S10-15)

In some texts, notably from Roluos (late $9^{\text {th }} \mathrm{c}$.) and Koh Ker (ca. CE 928-944), personnel are listed hierarchically in the hundreds, according to their roles in the temple. Yet provision for these staff might be indicated in only very general terms, as in K. 256 (CE 984: II, 36), "subsistence for those in service" or as allocations of rice to personnel, exemplified in K. 56 (B28-31). Occasionally, necessities for their roles, such as clothing, were also given. K. 989 (C10) records that on festival days the $p u$ rohita was given "1 yau of replacement garments and, as dakșinā (fees), 2 je of paddy." Angkorian inscriptions never mention provision of food other than rice for temple personnel. Yet vegetables and some protein must have been consumed. Burton Stein (1980: 164-165), writing about Coromandel Chola period brahmadeya villages, noted a "lack of specificity" in some inscriptions about how endowments were to be effected. He argued that neither the donor nor the temple functionaries could have been indifferent. Rather, while it was important to record the act of donation, the procedures for fulfilling the obligations were so well known and understood, there was no need to write them down. For Angkorian practice, albeit for deities, we might note stanza XLII of the Ta Prohm inscription K. 273 (CE 1186), where it is stated that, "The accessories for oblation such as fruits, vegetables etc., are not specified here: as these are well-known items, one can rely on customary practice."

Most Angkorian accounting differs markedly from the very detailed records of provision in some Sri Lankan and South Indian inscriptions (Hultzsch 1987; Ismail 1984; Wickremasinghe 1912), which are set out systematically according to the role of the worker. One text from the Tanjavur temple specifies the shares allocated to the workers, where they will be housed, and the entitlements of their relatives.

[...] and transferred (a number of) temple women from other temple establishments of the Chola country as temple women of the lord of the Srî-Râjarâjêśvara temple. To (these persons) shares were allotted as allowance. (The value) of each share (which consisted of the produce) of (one) vêli of land, was to be one hundred kalam of paddy [...] Instead of those among these shareholders, who would die or emigrate, the nearest relations of such persons were to receive that allowance and do the work. If the nearest relations [....]

To [Ś]ê[ra]man்[gai], a girl (who has been transferred from the establishment of the temple) of [...], (and who resides in) the first house of the southern row of the temple street on the south (of the temple), one share.

[Similar for another 401 women]

Râjarâja Inscription 66 (ca. CE 1014)

In some Chola inscriptions, the resources used for maintaining the temple operation were calculated accu- 
rately: donated money was loaned out to village communities and the interest was computed at $12 \frac{1}{2}$ percent per annum. This was converted precisely to an annual quantity of paddy based on a fixed price and then revalued in terms of other commodities also at fixed exchange rates (Hultzsch 1987 II: 18, 75, 149). The interest could then be repaid in kind or cash and used to maintain temple rituals (Hultzsch: 74-75).

[...] the members of the assembly of [...] [have received from ...] who has been pleased to take up gladly his abode in (the temple called) Śrī-Rājarâjêśvara at Tañjâvûr, - 500 [kấsu] out of the money, which [...] had deposited for the requirements of this (image). For (these $500 k \hat{a} s i$ ), we have to pay each year from [(the harvest of)...] as long as the moon and the sun shall endure, an interest of $621 / 2 k \hat{a s} u$ into the treasury of the lord of the Śrī-Rājarâjêśvara (temple) — the rate of interest being 1/8 kâśu per year for each kâśu.

Râjêndra-Chôla Inscription 15 (ca. CE 1034)

In Angkorian foundations, the temple auditors must also have documented the input and output of resources in detail to ensure their smooth operation. A stanza of inscription K. 1002 (1022: XXVIII) appears to refer to accounting activities within the temple: "His palace was filled each day with groups occupied entirely with doing the accounts for the accessories (of ...), as if there were no other occupation." Such records are now lost. Yet, while the degradation of documents on plant material may account for the loss of much information, it cannot explain the apparent inconsistencies and instances of excessive precision found in those stone inscriptions that allow analysis of their temple accounts.

\section{ACCOUNTING}

\section{$A$ varying unit of measure}

One complication encountered in analysing the accounts is that the scale of Angkorian weights and measures appears to have varied over time, at least for rice. In an addendum to George Codès' translation of the Ta Prohm inscription K. 273, Palmyr Cordier (1906: 82) examined the scales used for the prescribed commodities. He proposed that the Sanskrit scale of weight and capacity for rice was as summarised in Table 1, and put forward equivalent metric weights for each unit. Cœdès (1941: 291, n.2) demonstrated in his translation of the Preah Khan inscription K. 908, that the recorded total of two given quantities of rice (LXLIV, LII, LIII) ${ }^{5}$ followed the scale in the first column of Table 1.

Cordier (1906: 82) assigned the metric weights on the basis that this scale was from the Māgadhaparibhāsāa as set out in the Caraka Samhita ${ }^{6}$ (Sharma 1998: 581) -

\section{5 khārīkā 1/2 droṇa +22 khārī 2 droṇa 14 prastha $=97$ khārī 3 drona 6 prastha}

6 This text traces its origins to a treatise by Agniveśa in the early Buddhist period (Ray and Gupta 1965: 9), and revised by Caraka some time between the $7^{\text {th }} \mathrm{c}$. BCE (Sharma and Dash perhaps because many of the units of weight and capacity used in the Ta Prohm inscription were more in accordance with this source than with other texts. ${ }^{7}$ Yet no reference to the Caraka Samhitā has yet been found in the Angkorian epigraphy, while another text, Suśruta Samhitā, is mentioned in K. 323 (CE 889: 49) of Yaśovarman and Rājendravarman's K. 528 (CE 952: LXXIV). However, the Suśruta Samhitā lists only some of the units used in the Khmer inscriptions. ${ }^{8}$

\section{Table 1: Scale of measures proposed by Cordier}

\begin{tabular}{ll}
\hline $\begin{array}{l}\text { Sanskrit measure of volume used for } \\
\text { grain }\end{array}$ & $\begin{array}{l}\text { Equivalent weight, } \\
\text { kg }\end{array}$ \\
\hline kuḍuva & 0.373 \\
prastha (4 kuduva) & 1.422 \\
āḍhaka (4 prastha) & 5.971 \\
droña (4 āḍhaka) & 23.884 \\
khārī (4 droṇa) & 95.539 \\
\hline
\end{tabular}

For the much-studied Trapeang Don On inscription K. 254, bilingual in Sanskrit and Khmer, Cœè̀s (1951: 181, n. 4) postulated that the Khmer units of weight were close to the Sanskrit ones, and in two sets of corresponding verses, they appear to be equivalent. ${ }^{9}$ However, as the two left-hand columns of Table 210 show, while

2001: ii) and the $2^{\text {nd }}$ c. CE (Ray and Gupta 1965: 11).

7 Scales in other Indian texts contain units with the same names as those in Table 1 but with ratios between them that are different. In the Arthaśāstra (Olivelle 2013), and the Śārngadhara Saṃhitā (Murthy 2001: 3), one khārī equals 16 droṇa, not 4 drona as with the Caraka Samphitā.

8 The scale of Caraka appears to be based on seeds such as mustard and barley, while the scale of Suśruta is based on rice grains and the seeds of unspecified pulses, possibly peas, beans or lentils. Yet even where the same seeds are specified, the multiples can differ. For example, in the Caraka Saṃhitā, a guñja or Abrus seed weighs the same as 4 big mustard seeds, while it weighs 32 of them in the Suśruta Saṃhitā (Bhishagratna, 1911: 548). D. B. Ellepola (1936: 127) noted this too for scales of weight in Sri Lanka, suggesting that as travel was then mostly localised, a lack of uniformity would likely not be "any great inconvenience".

9 Two Sanskrit stanzas corresponding to two Khmer lines suggest that the units are equivalent: the daily offerings of 2 a dihaka less 2 kuduva to the 3 Gods and the Fire, in the Sanskrit stanzas XIX-XXI, being equivalent to 7 lih 2 'var in Khmer lines 23-25; and the Sanskrit stanzas XVII-XVIII having 14 khārī 1 droṇa 13 prastha 1 kuduva, with the corresponding Khmer passage B29-33 having the amount 14 thlvain 1 je 13 lih 1 'var.

10 Cordier's (1906: 82) scale is for weights. For liquids, the weight value multiplied by 2 gives volumes of the same names. In K. 273, Cœdès (1906) assigns the same units for weight and capacity to non-liquids, including rice. (See, for example, his Note 3 on page 76.) Thus rice weighing one prastha filled a container with a volume of one prastha. In the introduction to his translation of K. 254, Coedès (1951: 18) points out that this text was the basis for establishing the table of equivalence of 
Cœdès (1951: 188, 191) took one droṇa to equal 16 prastha, he suggested 1 je was equal to 15 lih — to allow calculated totals to equal or approximate the stated totals in this inscription. ${ }^{11}$

Table 2: Two interpretations of correspondence of Khmer and Sanskrit units of weight and capacity

\begin{tabular}{|c|c|c|}
\hline Khmer & Sanskrit (Cœdès) & Sanskrit (Soutif) \\
\hline 'var & kuḍuva & kuḍuva \\
\hline lih (4 'var) & prastha (4 kuduva) & prastha (4 kuduva) \\
\hline ? & āḍhaka (4 prastha) & āḍhaka (4 prastha) \\
\hline je (15 lih) & drona (16 prastha) & drona (15 prastha) \\
\hline thlvan (4 je) & khärī (4 drona) & khärī (4 droṇa) \\
\hline
\end{tabular}

Yet this hypothesis fails for another part of the same inscription, ${ }^{12}$ from which Dominique Soutif (2009: 138) concludes, logically, that for K. 254 at least, a drona was 15 prastha (right-hand column of Table 2 ), which is the same as the Khmer ratio. Thus, while in K. 273 (CE 1186) a drona or je equalled 16 prastha or lih, in K. 254 (CE 1129 ) it was 15 , raising the possibility that the ratio changed some time after the latter inscription was written.

\section{Addressing some ambiguities}

Numerals have often altered substantially over space and time in both India and Southeast Asia (Renou and Filliozat 1953: 703-708; Soutif 2008), and are sometimes difficult to distinguish from each other. This is so for the Old Khmer digits for 4 and 5 (e.g. Codès 1942: 89, n. 4, Soutif 2008: 56). In lines B39-C1 of the Prasat Beng inscription K. 989, the daily offerings were made to five gods. However, lines $\mathrm{C} 2$ and C6 refer to only 4 divinities, and line $\mathrm{C} 5$ prescribes 4 je per day of rice to be offered up in Kārttika, arguably 1 je for each divinity (Cœdès 1964: 177-178). An examination of an image of these lines on the stele (rubbing: EFEO-n1271c) shows, in fact, that the offerings are to be made to the 5 divinities mentioned earlier, with $1 j e$ per day for each of them during Kārttika. This apparent anomaly was thus simply a misreading.

The numerous instances, where quantities of milled rice or paddy are stated without a unit of measurement, presented us with a different ambiguity. The unstated 'measure' is commonly the largest unit recorded and is

measures of "capacity" for rice between Sanskrit and Old Khmer.

11 For example, the Khmer lines B35-38 record the provision of 8 thlvan 3 je 2 'var of rice from designated riceland for the subsistence of temple workers (khñum vrah). This amounts to 2,266 'var, whereas the Sanskrit stanza XXIII states that this quantity is 2,126 kuduva. Following Cœedès' hypothesis, the Khmer amount would also be 2,126 'var. The same point can be made for Khmer lines B34-35 and Sanskrit stanza XXV.

12 If Cœdès' hypothesis is applied in stanzas XVII-XVIII, the Sanskrit amount would total 3,701 kuduva, while to reach the equivalent amount in Khmer units, 3,701 'var, the Khmer lines B29-33 would have to be 15 thlvan 1 je 10 lih 1 'var, not 14 thlvan 1 je 13 lih 1 'var. often rounded to the nearest 10 or 100 . In three inscriptions - K. 726 (CE 678-777), K. 353S (CE 1046) and K. 571 (CE 978-1077) - the 'measure' appears to be greater than the thlvan, since it appears first, as, for example, in the 20 (measures) 4 thlvan of paddy of K. 571 (16). In K. 989 however, the unstated measure is clearly a thlvain. In line C5 discussed above, where 5 je is offered up daily, the paddy required each year is given as "20 10 7 je 2", and interpreted by Cœdès (1964: 187) as "37 (thlvai) $2 j e$ ". It is a simple matter to see that in a fortnight of 15 days, the measure should equal one thlvan. For the records in this inscription to have been consistent, the same interpretation should apply to lines C1-2, C5-6 and $\mathrm{C} 7$, to be discussed below.

Inconsistencies in the calculations for the allowances can be discerned in a few other texts. For example, totals are sometimes not the sum of their parts. Cœdès (1924: 351, n.3) examined the measurements of land in K. 397 (CE 1112: E5-12) carefully, and concluded that no matter how the digits were interpreted, the total length was less than the sum of the individual parts of the perimeter boundary. We see this too in the totalling of lists of working personnel in K. 99 (CE 932: N17-18), K. 143 (CE 977: A27) and K. 263 (CE 984: D31). In K. 254, the text states the volume of rice for the deities for the waxing and waning fortnights over one year to be 28 khäri 3 drona 11 prastha 2 kuduva. The issue here is that while the total should be 6,946 kuduva, ${ }^{13}$ the amount is said to be 6,926 kuduva. In K. 989 (C7-8), the following apparent discrepancy could have been one of transcription. The total paddy for maintaining the gods for 1 year is given as 2 slik $^{14}$ 100 (+) 80 thlvain 2 je, or 980 thlvan 2 je. This should be the sum of various allocations given in lines B41-C1, which however, add up to 1,097 thlvan, ${ }^{15}$ or 1,074 thlvan if the amounts rounded off in the inscription are used. ${ }^{16}$ Thus the yearly total could have been more accurate if stated as 1,080 thlvan 2 je (2 slik $200(+) 80$ thlvaí 2 je) - a transcription error of 100. In the same inscription, we see also on line C7 that the total paddy offered up for the festivals is 130 thlvain each year. Yet when the paddy

13 See Sanskrit stanzas XVII-XVIII. From the scale of measures in Column 3 of Table 2, this is calculated to be $(28 \times 240+3 \times 60+11 \times 4+2)$ or 6,946 kuduva. The equivalent Khmer lines are B29-33.

141 slik $=400$

15 Here $1 j e$ is taken to be 15 lih (Section 3.1).

16 In K. 989 , daily offerings to five gods are set out in detail, but the stated total of rice required is not equal to the sum of the individual items being rounded to the nearest $j e$. For example, the daily offerings to the Śivalinga (B41-43) amount to 28 lih, which is rounded up by 7 percent to 2 je $(30$ lih), while the allocation to the Parameśvara (B43-45) totals 17 lih, which is rounded down by 12 percent to 1 je (15 lih). 
required for each festival $(\mathrm{C} 1-7)$ is added, the total is close to 103 thlvan. This could be more than a simple transposition of digits, since the number 130 was written as $100(+) 20(+) 10$, whereas in the context of this inscription, 103 might have been written $100(+) 3$. In highlighting errors such as these, we do not suggest that they are remarkable in a medieval society in which likely few people were literate and numerate. Indeed, as the endowments and allocations would probably have first been written on palm leaf or the like, and then copied at least once before being inscribed, it is understandable that errors may have been made.

\section{Excessive precision}

What appear to be errors of a different kind are records of quantities detailed down to very small units. On first encounter, these seem to affirm high accuracy on the part of the auditor. However, there are records of quantities of rice whose extreme precision is curious. For example, what is the significance of the 2 kuduva in an amount 6,946 kuduva in the example from K. 254 in the previous paragraph? Annual harvests could have been neither predicted nor apportioned with an accuracy of \pm 0.02 percent, which this implies.

In inscription K. 989 (C8), the total amount of paddy, milled rice and cooked rice needed for the daily offerings, as well as for all the festivals, is stated to be an annual volume of paddy, 3 slik 3 thlvan and 2 je. However, 1 je (or $1 / 4$ thlvain) in the context of about 1,200 thlvan implies an accuracy of 1 in 10,000 or \pm 0.01 percent. Such precision would have been almost impossible to achieve. Small amounts of rice were likely measured by scoops, perhaps of ceramic pots or hollowed-out coconut shells; larger quantities might have corresponded to baskets that could be carried by people, or by carts (Antelme 2011). One slik of paddy might have been the amount brought in by about 20 oxcarts.${ }^{17}$ Thus the 3 slik specified in this inscription might have been the quantity of grain delivered by 60 oxcarts. The additional 3 thlvan and 2 je would have served little operational purpose, being about a sixth of a cartload. Perhaps the administrators calculated the amount of rice by assuming a particular yield per unit area and multiplied this by the total area. But, given that harvests vary from year to year, and that the luni-solar year varied between 354 and 385 days (Eade, 1995: 57), as well as the vagaries of measurement, such precision seems pointless, and the total should logically have been rounded off to the nearest slik. The failure to round off is even more curious, given that, as we have seen, ${ }^{16}$ some totals were made up of daily quantities that were themselves rounded off - perhaps by as much as 12 percent. We are inclined to the view that the founder endowed a round amount annually, and then left it to the temple administration to determine the allocations for the gods and the festivals.

17 This is based on an oxcart carrying about $1.3 \mathrm{~m}^{3}$ of milled rice, and the bulk density of milled rice being about $800 \mathrm{~kg} / \mathrm{m}^{3}$ (IRRI, accessed 14/10/13).
What then was the significance of the additional 3 thlvan and $2 j e$ ?

A similar question stems from the offerings totalling 6 thlvan of rice for the Five Festivals at the same temple (C2-3). The inscription states that this quantity required 12 thlvan 2 je of paddy, which would imply a conversion ratio of 2.08333 . If the amount had been an even 12 thlvan, this ratio would simply have been 2 , a much more workable ratio. It could then follow that the additional 2 je of paddy had little to do with practical computations, particularly as the ratio used for calculating the amount of paddy needed for conversion to rice was always 2 in this inscription, as will be argued below.

In the Ta Prohm inscription K. 273 (XLV), the daily rice, 917 prastha, to feed either 970 people living with the reader or 1,409 - if we add to this the 439 holy men in the royal palace (LXXXII) - is specified to the nearest prastha. ${ }^{18}$ Is it credible for such an exact quantity to be meaningful for such a large number of people? ${ }^{19}$ Fluctuations in doling out so many meals would surely exceed a single prastha. Other instances of flawed accuracy can be found in the same text where up to 4 units of measure are employed for the quantities of commodities, such as honey (stanza LX), which was levied from villages. An even less credible display of precision is seen in stanza LIII, where it is written that paddy of 4,093 khärika 1 drona 2 kuduva is to be supplied by villages. One kuduva in about 4,000 khārika implies an accuracy of \pm 1 in 2 million, which would have been impossible.

These examples may point to a desire on the part of the auditors to demonstrate their proficiency in an esoteric occupation by providing some excessively - and possibly in some cases, fictitiously - precise details in their accounting. They may have been aware of records of land tax calculations, temple loans and entitlements in Indian temples, calculated in fine detail, and sought to appear equally skillful. ${ }^{20}$ The founders likely would not have objected to such displays.

\section{Rice conversion ratios}

Chola inscriptions value 5 measures of paddy as worth 2 measures of rice (Hultzsch 1987: 75, 129, 149). That paddy also had a fixed value in Karnataka is evident from local texts where workers were paid sometimes in money, sometimes in standardised volumes of paddy, or in both (Ismail, 1984: 131-134). Certainly during the latter part of the $13^{\text {th }}$ century, the price ratio of paddy to rice was consistently 5:2 (Ismail: 86-87). K.V.S. Aiyer (2013[1917]:

18 The sattra of the people who live at the teacher's house and at the reader's house: rice daily, 14 khāri 1 drona 5 prastha $=$ 917 prastha.

19 It is possible that the 5 prastha were included to satisfy the Sanskrit metre, but this could not explain the cases of excess precision in the prose of the Khmer texts.

20 Nevertheless, we have yet to see contemporary Indian examples of high precision that did not derive from calculations. 
375) has argued (for the Dekhan) that the ratio for converting paddy to rice was actually about $2: 1,21$ and that the extra (20 percent of) paddy was for the wages for pounding and cleaning the grain - as might be expected in a market economy.

In an Angkorian temple on the other hand, the labour of transformation need not have been accounted for. Temple personnel who grew, milled and cooked the paddy of temple lands (for example, the two rice pounders at a hospital chapel, mentioned in K. 368 [CE 1186: XXV]) would likely have been supported as part of the foundation establishment, so there would have been little need to allow for the cost of labour. Since the actual conversion ratio must have varied with type of rice, quality of harvest and degree of milling, it would have been practicable for the accountants to adopt a simple ratio, such as $2: 1$ or $5: 2$, close to what was observed. These ratios would need to have been kept constant, to make the calculations tractable. On the other hand, if specified quantities of paddy were to be provided to the temple from outside sources, it would have made sense to allow specifically for the labour entailed. In the Ta Prohm inscription K. 273, the ratio for converting paddy to rice is stated to be 4:1 (stanza LII), far greater than the physical conversion ratio of $2: 1$, possibly to factor in an amount for the labour of milling and the degree of refinement of the rice.

The results from reconstructing the accounts in K. 989 support our view that the ratio used for converting paddy to hulled rice at Prasat Beng was 2. This ratio is derived from the daily offerings of milled rice for a fortnight during Kārttika (line C5), for the month of Caitra (lines C6-7), and for the Five Festivals (lines C2-3), where in each case, the milled rice is half the volume of the paddy. ${ }^{22}$ The same ratio has also been obtained from lines B41 to C8 iteratively. 23

The same ratio of 2 was used for lines $\mathrm{C} 1-2$, where the 1 je of milled rice offered to each of the five divinities at the sankkrānta festival required 30 thlvan of paddy annual-

21 This is supported by evidence from modern hand milling, which indicates an even greater efficiency, the ratio derived from an Indonesian study being about 1.7 (Weitz-Hettelsater Engineers 1972: 722).

22 The small discrepancy in the amount for the Five Festivals is discussed above in Section 3.3.

23 Lines B41-C1 specify the daily allocations of milled rice to the gods, while lines $\mathrm{C} 1-7$ set out the allocations for various festivals in both rice and paddy. The total annual requirement for both is stated as paddy in lines C7-8 (the 3 slik 3 thlvan 2 je discussed in Section 3.3 above). Equating the sum of the amounts for the daily (rice) and festival (paddy and rice) offerings to the stated total (paddy), we obtain by trial and error a value of between 1.96 and 2.02 for the ratio for converting paddy to rice. This variation depends on the number of days in the year used in the calculations and whether or not anomalies discussed in this paper are incorporated. ly. (See A1 in Supplementary File 3.) Dividing the annual amount of paddy in je by the number of divinities, 5 , and by the conversion ratio of 2 , we find that the festival was celebrated 12 times, i.e. monthly. Jenner (2009) and Cœdès in his translations, interpret the festival of sañkrānta as being the New Year. ${ }^{24}$ However, Sanskrit dictionaries are less specific, interpreting it as the (celebration of the) passage of the sun or a planet from one sign or position in the heavens into another (MonierWilliams 2005), while Pou (2001) leaves the term untranslated. Sainkrānta might then conceivably occur annually (perhaps at the New Year), six-monthly or quarterly (according to the solstices and equinoxes), monthly (at the new moon or on entering a new constellation) or fortnightly (at the full and half-moons). The following lines from a royal order for allocations for an āśrama indicate that sankrānta was celebrated according to the passage of the sun, since not every saìkrānta was at a change in the moon's phase.

At changes in the moon's phase: two pāda of melted butter; two pāda of curdled milk; two pāda of honey; two 'var of fruit juice; at the sankkrānta [Cœè̀s trans. 'New Year'], one thlvain of milled rice; at changes in the moon's phase, only one je of milled rice; [...]

K. 391 (CE 1082: W27-30)

On the other hand, a text on a stele from Phnom Bayang, K. 850 (CE 1078-1177: 11), suggests sainkrānta at that temple marked the passage of the moon, and may have been a fortnightly event. Amongst the staff were "men for service at saíkrānta" for the clear fortnight. There is an equivalent direction for the alternate fortnight.

Another auspicious day mentioned in the same text, the tithiviśesana (a hapax), has been glossed as both "the first day of the lunar fortnight" (Jenner, 2009) and the "distinction of the tithi" (Cœdès). ${ }^{25}$ As a tith $\bar{\imath}$ is a lunar day, and viśeșaṇa implies a particularisation, tithiviśeșana could be one or more particular days in a lunar month. Since the number of tithiviśeșana per month must be a whole number, the stated 12 thlvan 12 lih of paddy per year for this festival would require 1 je to equal 15 lih, a paddy-rice conversion ratio of 2 , and 4 tithiviśessana to be observed per month. (See A2 in Supplementary File 3.) One possibility is that these days fell on the new moon, the full moon and the two half moons.

Our examination of the fortnightly offerings of 4 lih of rice for the 4 castes (line $\mathrm{C} 4$ ) exposed an anomaly, however. Given that the paddy-to-rice conversion ratio has been 2 in the rest of this text, it should be 2 here as well. We show in A4 in Supplementary File 3 that one je must then equal 16, not 15 lih as elsewhere in the inscription. We cannot arrive at a logical explanation for this.

24) This could be because today samkrānti is celebrated for three days at the New Year (Soutif pers. comm. 2015).

25 Cœdès 1964 (187, n. 1) cites M.K. Bhattacharya, who infers this meaning from the Viṣnudharmottara, I, 56, 18. 
The prescription in K. 989 (C5-6) for cooked rice in Caitra provides a strong indication of the volume conversion ratio used for milled to cooked rice, presumably being a whole or half number, for ease of calculation. The 3 lih of cooked rice required daily for the divinities over the month needed 3 thlvan 3 je of milled rice. For this statement to be correct, 1 je again had to equal $15 \mathrm{lih}$ and a unit volume of milled rice had to be considered as producing 2 units of cooked rice. (See A3 in Supplementary File 3.) Mohapatra and Bal (2006: 257) have demonstrated that the volumetric ratio of cooked rice to unbroken milled rice could vary between 2 and 4, depending on the weight loss through milling, which ranged between 2 percent and 18 percent in their experiment. The less the weight loss, the lower was the ratio (Mohapatra and Bal: figure 3). The conversion ratio of 2 in K. 989 thus suggests a low degree of milling.

\section{SUPPORT AND SCHEDULING OF TEMPLE PERSONNEL}

\section{Allocations of rice}

Three texts from Yaśovarman's āśrama, K. 701; K. 279; K. 290, tell us how much rice was allocated each day to different members of the community from the master down to young boys (LXXVII-LXXXIV). Young boys received 2 kuduva ( $1 / 2$ lih) to 3 kuduva ( $3 / 4$ lih), the amount presumably depending on their size or age. The young and old hermits and Vishnuites were allocated 1 prastha (or 1 lih), which Soutif (2009, p.141) has estimated to be $500 \mathrm{~g}$, on the assumption that this is what an average adult consumes per day. ${ }^{26}$ We agree with this approach in principle, but suggest that Soutif's calculations might be modified.

K.A.S. Murshid (1998: 15-16) has reported on an investigation of rice consumption in three Cambodian villages, one producing rice surplus to requirements, one with a rice deficit, and a fishing village. He found little variation between them, with the average being about $570 \mathrm{~g} /$ day for an adult. Murshid also found little variation in the contribution of rice to the total caloric intake $(\sim 80$ percent) across the socio-economic spectrum, implying that food energy intake was proportional to rice consumption. As the caloric intake varies with age, sex and the degree of activity of the person (Passmore et al. 1974: 613 ), adult males of a village could consume about 15 percent more rice ( $\sim 660 \mathrm{~g} /$ day) than the average of male and female adults (Passmore et al. table 1).

We can now estimate the value of the prastha (or lih). If the amount of 1 prastha assigned to young and old hermits were a subsistence ration, then the 2 kuduva for the youngest of the boys would feed children of only about 2-3 years of age (Figure 1). ${ }^{27}$ On the other hand, if

26 Soutif derives this from Groslier (1979: 41) and Gravelle (1915: 17).

27 See also Supplementary File 2.
2 kuduva was the allowance for boys of 5 to 6 years, and 3 kuduva (or 0.75 prastha) was the basic ration for the oldest boys aged 12 to 14 , this would accord more with their caloric requirements - in this we suppose that students would not be given rice surplus to their needs. The daily requirement for adults would thus have been about 0.77 prastha $($ lih $) /$ day. If we equate this amount to the 660 $\mathrm{g} /$ day for adult males (above), then a prastha (or lih) of milled rice might have weighed about $860 \mathrm{~g}$ and the khāri (or thlvain) about $51 \mathrm{~kg}$ if, as we have proposed in Section 3.1 , a thlvan was equivalent to $60 \mathrm{lih}$ at this time. ${ }^{28}$ Perhaps not by chance, a similar ration equivalent to $0.75 \mathrm{lih}$ (prastha) was given to the lowest ranking personnel in K. 989, a century later at Prasat Beng, when they were off duty (lines C22-27). ${ }^{29}$

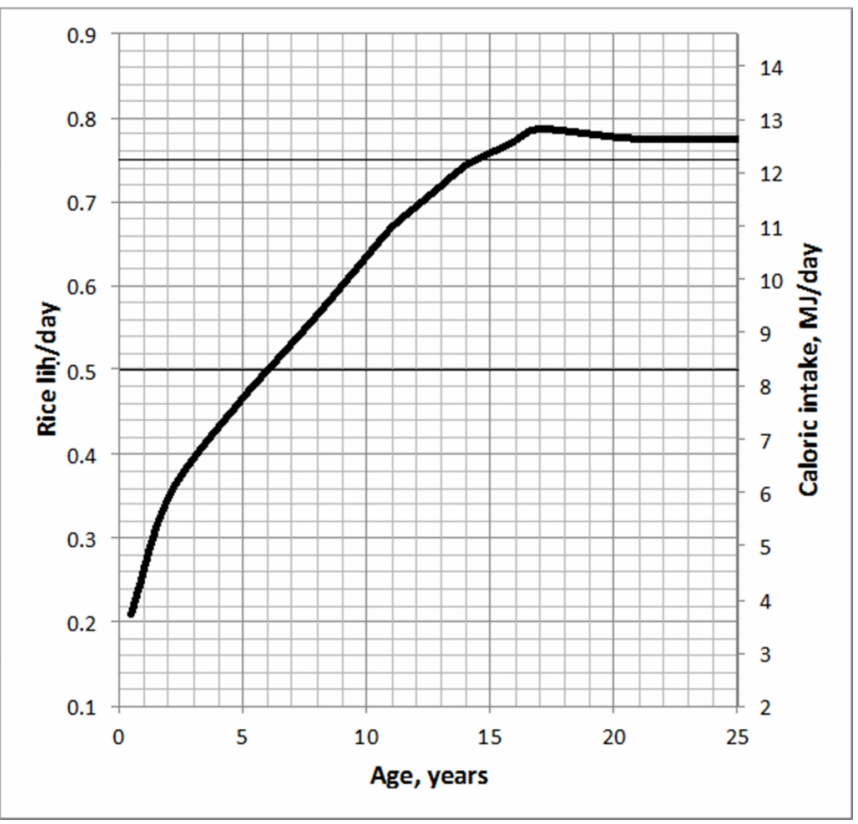

Figure 1: Caloric intake and rice consumption by age, adapted from Table 1 of Passmore et al. (1974)

This allowance might now be compared with the 917 prastha for the 970 or 1,409 "people at the residence of the teacher and the reader" at Ta Prohm (Section 3.3 above), nearly two centuries later again. If this quantity were only for feeding the 970 people with the reader, the amount of rice per person would have been 0.95 prastha per day, which is close to the one prastha provided to the

28 By comparison, Cordier (1906: 82) proposed that the khäri (a thlvain) weighed $95 \mathrm{~kg}$; Pou (1984: 145-6) and Michel Antelme (2004: 23) cited B-P Groslier's estimate of $59 \mathrm{~kg}$; Soutif (2009: 142) estimated the thlvain to be $30 \mathrm{~kg}$; while Antelme (2011: 350) notes that the modern tanlüin in the Khmer-speaking Thai province of Surin weighs between 220 and $276 \mathrm{~kg}$, and poses the question of whether the tanlün is derived from the thlvan. Regardless, we consider it highly unlikely that their values remained unchanged over centuries.

29 This assumes that 1 unit of rice produces 2 units of cooked rice. (See Section 3.4.) 
young and old monks in Yaśovarman's āśrama. If however, part of the 917 prastha also fed the 439 holy men, the average ration would have been 0.65 prastha per day. If the holy men were allocated $0.75 \mathrm{lih}$, it follows that that the 970 students received an average of about $0.6 \mathrm{lih}$, consistent with the 0.5 to 0.75 lih for the young boys in the ásrama. Under this scenario, the value of the prastha would not have changed much over three centuries. An alternative is that the 1,409 people all received the same ration and the value of the prastha had increased by about 15 percent in this period.

Mostly, the lowest ranking workers at Prasat Beng were allowed at least 2 lih of cooked rice per day (or 1 lih of milled rice) when they were on duty (lines C25-27). If they only required about $3 / 4$ lih per day to live as suggested by their off-duty allowance, they would have been able to retain the surplus of $1 / 4 \mathrm{lih}$. In addition, they were allowed generous amounts of rice on festival days. In Yaśovarman's ásrama, some of the allocation of 1 prastha (4 kuduva) to the young and old hermits could also have been surplus to their needs. Further, the elite in these establishments were given 11/2-3 prastha (lih) per day.

Yet in K. 254, even the elite seem not to have received enough to live on. We see on line B24 that 7.5 lih per day, which equates to about 10,620 'var of hulled rice per year, were provided for the establishment of the "cult of the three gods and the Sacred Fire" annually. ${ }^{30}$ Now the total ' $v r o h$ ' of four assigned ricefields ${ }^{31}$ comes to approximately the same amount, 10,672 var (lines B33-35). Thus the only acknowledged sources of rice for the whole establishment were these four ricefields. Vroh has been interpreted variously to mean 'productivity', 'capacity', 'yield', 'perimeter', 'area', 'to sow', and 'a measure of seed to sow a ricefield' (Cœè̀s, 1937-1966, Jenner, 2009, Pou, 2001), and these would normally imply that the commodity was unhusked rice. However, since line B24 states explicitly that the quantities offered to the foundation are in milled rice, here vroh should mean 'the milled rice obtainable from the given ricefields'. This interpretation is also possible where vroh is used in other Angkorian texts. Three of the four assigned ricefields providing vroh of 3,746 'var went directly to personnel. It is straightforward to determine that the officiant was allocated 0.62 lih per day, the chaplain 0.51 lih per day, and sanctuary slaves still less. Even if the vroh from the fourth ricefield reserved for the deities, 6,926 'var, was subsequently allocated to these individuals, it would still not

30 A lunar year has been taken as 354 days, 6 months with 29 days and 6 months with 30 days (Eade 1995: 57).

31 The four fields are: for holy worship (6,926 'var); for the officiant(s) (897 'var); for the purohita (741 'var); and for the khñum vrah (2,126 'var). Although Jenner and Codès interpret smin as 'officiants', its precedence in the text and the amount of rice suggest to us that there was only one officiant. have been sufficient to support them. ${ }^{32}$ They must have received additional food, perhaps from their villages or other temple lands, by growing it, or even through the trading of high-value sacrificial offerings, which is seen in India today.

In K. 989 (C7-8; C27-29) and even in K. 254 (B3538 ), we see that the gods were offered roughly double the amount allocated to temple personnel and infer that this was not wasted. In K. 368 (XXVII), a Jayavarman VII hospital chapel, the daily leftovers were to be given to the sick. Inscription K. 684 (CE 878-1077: 15-17) indicates that sacrificial food was allocated to the elite. In this text, yajnaśeșa, what is left [to be performed] of a sacrifice, or the remains of the sacrifice (Jenner 2009), seems unambiguous. The deity received an offering of 1 je. Five somewhat prestigious individuals associated with the temple were then allotted all of this. 33

Allowances owing to the kamraten jagat at Vnam Kantāl by the vrah kamraten of Vrah Thkvāl: 1 je of milled rice at the sankranta. [...] The remains of the sacrifices (are thus distributed): 5 lih to the inspector of the royal service; 2 lih to the venerable (bhagavan); 1 lih to the guard of the treasury; 1 lih to the guard of the holy registers; 6 lih to the person performing that sacrifice.

K. $684(15-17)$

The provision of ricefields for the subsistence of some sanctuary workers is documented in only three inscriptions: in K. 254 (CE 1129: B35-38) for the khñum vrah; and in K. 754 (CE 1308: B12-13) for officials, kamraten 'añ. The allocations in K. 702 (CE 1025) are for certain temple personnel, though apparently not for a number of lower status khñum listed at the end.

Two ricefields southwest of the Ulloka reservoir are reserved for the ...: to the west of this reservoir, for two cooks; to the north of that reservoir, for two leaf

32 Twenty-one people (not counting five children) were receiving rice from the temple ricefields, so the 6,926 'var available annually from the ricefield for the cult of the gods would, on average, have provided $0.23 \mathrm{lih} / \mathrm{person}$. When added to the official allocations, this would have been enough for the officiant $(0.84 \mathrm{lih} / \mathrm{day})$ and the purohita $(0.74 \mathrm{lih} /$ day $)$, but well short of adequate for the khñum vrah (0.31 lih/day, barely enough for a 1-year old). An alternative explanation, that the value of the lih at Trapeang Don On was two or three times greater than at Ta Prohm 57 years later, is possible, but in our opinion, unlikely. This foundation was located less than $15 \mathrm{~km}$ from the centre of Angkor, well within its influence, and where the Ta Prohm would be built. One additional possibility is that the khñum vrah at Trapeang Don On received enough to live on, while those in the Yaśovarman ásrama and those living with the professor at Ta Prohm received two to three times more than they needed. We consider this too to be unlikely.

33 We note here that the 1 je was equal to 15 lih as in K. 254, which was written one to two centuries later. (See Section 3.1.) 
makers; To the east of that reservoir, for ... musicians; to the south $\ldots$ of that reservoir and the jranyain tree(s), for two dancers and singers; inside the delimited land, near the jranyan tree(s) for doorkeeper(s) who guard ...; [...]

Khñum offered to the temple: [29 named].

Did the temple maintain them, or did they rely on other sources? Whatever the case, we can see from the few examples we have discussed here, that the mode of support for temple workers was far from uniform. Perhaps perspective might be gained through some appreciation of the institution of the fortnightly work schedule.

\section{The fortnightly work schedule}

The Angkorian inscriptions K. 258 (CE 1107: A80) and K. 989 mention people, mainly officiants, working in shifts or in turn (vera), the latter being the only text where we see allowances to personnel both on and off duty. The length of each shift is not specified. Nevertheless from the late $9^{\text {th }}$ century, other texts refer to temple work groups or individuals assigned to either the period of the waxing moon (khnet) or the waning moon (noc), i.e. half a lunar month or a fortnight each. ${ }^{34}$

Slaves to provide what is due: tai Kanso; another tai Kanso; tai Kamvṛk; tai Thkon; tai Kañcan; si Vṛddhipura - these for the fortnight of the waxing moon. [For] the fortnight of the waning moon: tai Kandhan; tai Kạ̣bh $\square$; si Kaṃvit; tai Samākula; si Saṃ’ap; si Kamvai.

\section{K. 374 (CE 1042: 9-12)}

The lunar half-month in Southeast Asian calendric systems derived from the Hindu version, is 15 tithi, or lunar days, the mean average time between full and new moon. From K. 391 (W18-19), we know some Angkorian temples had a resident astronomer/astrologer (hora) to calculate when auspicious days would start and finish: "khloñ vala ta rap hora vrah kamraten 'añ ta sin phon pratipaksal" (the commandant who reckons the hours of the vrah kamraten 'añ who are on duty during both fortnights). The astronomer would have determined when new phases of the moon would start, and temple workers on one fortnightly shift might be relieved. The fortnightly categorisation of the workforce appears unique to Angkor. It may have arisen as a logistically appropriate way of rostering large numbers of people such as those recorded in the texts of Roluos from the late $9^{\text {th }}$ century, maintaining them only when they were on duty. This practice is referred to in at least 46 texts. The earliest example is from K. 809 (CE 878-877), while the latest inscription found to mention fortnightly service is K. 754 (CE 1308).

34 In pre-9th century texts, the terms are seen only in personal names. The transliterated K. 1004, dated to CE 691, includes fortnights, pratipakșa, on line 12, but Michael Vickery (1998: 358-9) considers the text unreliable, and it contains Angkorian forms.
Many inscriptions, containing substantial detail - titled officials, long lists of sanctuary personnel, endowments, temple property - make no mention of fortnights, so we cannot know how widely the system was used.

Under the fortnightly schedule, foundations typically had ricefields with workers dedicated to one or other of the fortnights. In this system, personnel working within the sanctuary - clerics, dancers, musicians, cooks, guards, etc. - were also categorised as working for one of the fortnights. People were appointed to manage the foundation's ritual calendar, land, labour and assets for each fortnight. Thus, the K. 71 (CE 878-977) refers to cow stables and $d m \bar{a} r$ (requisitioners) of paryyan (oil) for each fortnight, as well as guards assigned to the cattle stabled in sheds allocated to each fortnight - all under the authority of a mrateñ, Keeper of the Palace Gate for the clear fortnight. The Samrong inscription, K. 258 (A33-41) lists servants assigned to the god of Lingapura for each fortnight; individuals authorised to manage the foundation during each fortnight; and the locations of land and gardens allocated for each fortnight. K. 391W mentions a purohita for each fortnight, while K. 207 (CE 1042) refers to "vrah kralā glāं pratipakṣa" (the holy stores/chambers of the [temple] treasury for each fortnight). At Vat Baset (K. 207 and K. 208, CE 1042) and Nom Van (K. 391W), the duty roster for each fortnight is divided further into morning, midday and afternoon. Cœè̀s' translations of two texts, K. 754 (B12-13) and K. 850 (11) refer to personnel seemingly in residence during alternate fortnights, but these interpretations are open to question. In the first, Cœdès glossed sin as reside. Another interpretation, which we consider more feasible, is to preside over a ritual (Jenner, 2009, Pou, 1992). In K. 850, the passage uses the word vasana (a garment), yet is translated as "men in service during the sankrānta residing there during the clear fortnight". We suggest it might be interpreted as an allowance of garments for the people celebrating the saíkrānta during the clear fortnight.

Little has been written about the working fortnight. Mabbett noted that teams of 'slaves and goods' were 'available to the temple' only on alternate fortnights and argued that, on their fortnight off, temple personnel may have worked to support themselves. A second proposition mentioned by Mabbett is that for some, working for the temple was a form of usufruct and that during alternate fortnights they may have continued to work for those who had donated them. However, this remains conjectural, as some of the classifiers, which might explain the precise status of workers, are not fully understood (Mabbett 1983: 50-51). Mabbett did not distinguish between field and sanctuary workers. For the field workers, the tasks associated with rice cultivation, such as planting and harvesting, are determined by the seasons, and it would have been difficult for them to undertake fieldwork for only half the time at key periods in the year. However, rice producers would likely only have been required to provide a temple with a specified quantity of rice for a particular fortnight from temple or village lands, so their working schedule 
would not have been constrained by the fortnight. In K. 809 (8-9; 11-14; 19-26), some villages supplied teams for only one fortnight while one village supplied a team for each of the fortnights.

Let us now consider the sanctuary personnel, who lived within or close to the temple precincts (Evans et al., 2013: 3-4). In K. 809 (3-9; 14-19), K. 383 (CE 1121:

Columns 1-6) and K. 852 (CE 1107: 5-10) each of two sruk provided the workforce for separate fortnights, while in K. 218 (CE 1049: N12-59) workers for both fortnights were allocated from a single sruk. Again, the absence of a team every second fortnight may have been disruptive, especially during rice production periods - particularly if they were a large proportion of the village population. We suggest that it was more likely that the temple personnel were maintained when off duty primarily in ways other than by growing rice: by their villages or donors; by an allowance; from the remains of offerings; or, hypothetically, through trading, where high-value sanctified food was exchanged for unconsecrated goods. Which of these options were adopted for a particular temple, and whether in fact the schedule was by fortnights, would have depended to some extent on its income and its popularity with pilgrims.

There are indications that the fortnightly organisation extended to some functionaries of the state. In an inscription from Kampeng Nai, K. 374 (5-7), we see "trvac vra[h] rājakāryya pratipakșa" (an inspector[s] of the "royal service" for both [or each] fortnight), mentioned among witness to the purchase of land. In some instances, for example K. 256 (III, XVIII), foundations or their workers were decreed not to be subject to the vrah rājakäryya, the authority ostensibly representing the state in matters of levying of resources and corvée, while in

K. 212 (CE 1027: A25-28), we see a royal order that four ásrama should only be the concern of inspectors of the vrah rājakāryya, and not that of district chiefs. In K. 380

(CE 1038: 33) and K. 684 (CE 878-1077: 15-16), officials of the vrah rājakāryya were attached to religious foundations. Arguably, certain government roles were carried out under the auspices of temples, as there was often little demarcation between state and temple administration. Sedov (1963) suggested that there were prominent temples which acted as centres for collection of taxed resources for the capital. Mabbett (1978: 30-32) considered that local economies were centred on temples, which in turn had religious and bureaucratic links to state authorities. If so, the rajjakarryya would have had a presence there. Indeed, the rājakāryya seen in K. 380 and K. 684, and the 'fortnight' appellation of this official in K. 374, indicate that in these instances at least, the role was at the temple. We might ask whether rājakāryya pratipakșa were responsible for levying only temple resources or for taxing the general population as well. If the latter, then the fortnightly rostering might have extended into the secular community, perhaps for matters such as corvée. Whatever the motive for dividing the sanctuary workforce into fort- nightly teams, its broader consequences deserve to be investigated.

\section{DISCUSSION AND CONCLUSION}

While many societies with complex administrations have adopted money to simplify payments for goods and services, we should not assume the one entails the other (von Reden 2007: 31; Wicks 1992: 313). Angkor with its extensive territories between the $9^{\text {th }}$ and $13^{\text {th }}$ centuries, and complex bureaucracy illustrates this point. Further, an economy without money need not be associated with a low understanding of mathematical principles nor be without standardised weights and measures. We know that the Khmer had the ability to measure weights or capacities to a fraction of a gram and we argue that temples must have kept accounts.

We cannot be certain about the extent to which the weights were standardised - that is, whether terms represented different quantities in different locations and at different times, as in India. It was not clear whether the stated quantities of allocations to residents of a temple during the reign of Jayavarman VII represented roughly the same amounts as under Yaśovarman three centuries earlier, or whether the value of the prastha (or lih) changed significantly. On the other hand, we have seen that the ratio of lih to je changed only slightly from 15 in the mid- $12^{\text {th }}$ century (K. 254) to 16 in the late $12^{\text {th }}$ century (K. 908), and have estimated that at the turn of the $10^{\text {th }}$ century at least, the $l i h$ weighed between $800 \mathrm{~g}$ and $900 \mathrm{~g}$.

The rice conversion ratio used for daily and festival offerings in the Prasat Beng inscription was found to be 2 or close to 2 consistently, though this could not be confirmed for any other Angkorian inscription. As the allocation of rice was given for each festival offering, together with the yearly total of paddy, this allowed us to calculate the frequency of the festivals of sankrānta for this temple. We see that sankrānta may have been marked by different astronomical events at two other temples. A similar calculation indicated that tithiviśeșana, a hapax, was observed twice fortnightly at Prasat Beng. These calculations were valid on the basis that 1 je equalled $15 \mathrm{lih}$, not $16 \mathrm{lih}$, albeit with one exception. By the same reasoning, we showed that the volumetric ratio of cooked rice to rice was also taken as 2 .

The conversion ratio from paddy to rice of 2 differs appreciably from the ratio of 2.5 seen in Chola and Sri Lankan texts, indicating that labour was not accounted for at Prasat Beng. We would expect this to be the norm in other religious institutions where temple labour was maintained in-house. We see in several inscriptions that the elite were given more than they would need, being able to profit substantially, and even lower-status temple personnel received more than basic rations. Personnel at this temple were given reduced allowances when off duty and these may have been sufficient to live on. At Trapeang Don On however, the allocations to both the lower status khñum vrah and the clerics were probably inadequate, implying that their support was supplemented from other sources. An unrecorded additional donation seems unlike- 
ly, since a founder would not have recorded part of the foundation's endowment in detail and left the rest unrecorded. The stele of K. 254 appears complete, without lacunae. Foundation personnel could receive food remaining from the offerings and could supplement their revenue through their own efforts, which seems likely where there was fortnightly (or other) rostering. In a number of inscriptions, this scheduling involved the whole workforce, including elites. While different teams of field workers from the one village could be assigned to produce their annual quota for each of the two fortnights, we remain unsure how the temple personnel supplemented their income during their times off duty. For the temple as a whole, we envisage that there could have been profitable activities, one being the trading of sanctified food to pilgrims. In view of the fact that the offerings to the deities were considerably more than what was allocated to personnel, opportunities for augmenting earnings among some or all of the staff may have been available.

That the rhythm of some sanctuary workers' lives was regulated according to the lunar fortnight implies that the communities they belonged to were affected as well. In a sense then, the fortnights might have extended beyond the temple. As well, the instances of an official of the rājakāryya classified according to fortnights and of others based at temples prompt an intriguing thought that perhaps the fortnightly scheduling seen in some religious foundations had some relevance in the secular world as well. But this would depend in part on how widespread the practice was.

Scheduling the fortnightly and festival activities required well-trained astronomers with the mathematical ability to advise the foundations when the auspicious periods began and ended. The founders too had a vested interest in having people with the skills necessary for ensuring proper accounting, and while we may find errors in the calculations, these were not critical. Such errors as are to be seen probably resulted from multiple transcriptions and might be better understood if we remind ourselves that the stone inscriptions were not working documents. Our understanding of the calculations discussed here seems to have been confounded by what appears to be embellishment of the numbers, implying precisions that were false, and sometimes impossible to achieve. The inscriptions were primarily concerned with recording endowments of religious foundations and ensuring sustainability of the ritual, attributing merit, confirming ownership of land and genealogy, and securing entitlements. In such a context, perhaps an appearance of precision was important for the founders and an opportunity for auditors to make their skills manifest.

\section{ACKNOWLEDGMENTS}

We would like to acknowledge our sincere debt to Philip Jenner, whose loss in 2013 we mourn. We also thank Doug Cooper and the SEALang Project, Chris Eade, Arlo Griffiths, Stephanie Majcher, Pierre-Yves Manguin, Christophe Pottier, Joseph Rickman, Dominique Soutif, and three anonymous reviewers for their constructive comments. The K. 989 digital images were courtesy of EFEO.

\section{REFERENCES}

Aiyer, K. V. S. 2013[1917]. Historical sketches of Ancient Dekhan, London: Forgotten Books. Available: http://www.forgottenbooks.org/readbook_text/Histo rical_Sketches_of_Ancient_Dekhan_1000194608/1 [Accessed 26.6.2014]

Antelme, M. 2011. Quelques considérations sur deux mesures de capacité en vieux Khmer et leurs possibles équivalents en Khmer moderne : les cas de tlon, thlon, thlvain ou tanlonin (etc.) et $d n \bar{a} l$. Journal Asiatique 299: 319-367.

Antelme, M. R. 2004. À propos d'un texte sur les nombres, les mesures traditionnelles, etc., rédigé par le Hluon Bibhăkti Dhān̄̄, Yokpăt de Chrui Changva, pour Adhémard Leclère. Siksācakr 6: 20-32 (Khmer version 83-106).

Bhishagratna, K. K. L. 1911. An English translation of the Sushruta Samhita. Vol. 2. Calcutta: Published by the author.

Cœdès, G. 1924. L'Épigraphie du Temple de Phimai. Bulletin de l'École française d'Extrême-Orient XXIV: 345-358.

Cœè̀s, G. 1932. IV Études Cambodgiennes. XXVIII, Quelques suggestions sur la méthode à suivre pour intepréter les bas-reliefs de Bantây Chmàr et de la galerie extérieure du Bàyon. XXIX, Un nouveau tympan de Bantây Srei. XXX, À la recherche du Yaçodharaçrama. Bulletin de l'École française d'Extrême-Orient XXXII: 71-112.

Cœdès, G. 1936. La plus ancienne inscription en Pali du Cambodge. Bulletin de l'École française d'Extrême-Orient XXXVI: $14-21$.

Cœdès, G. 1937-1966. Inscriptions du Cambodge. Collection de textes et documents sur l'Indochine. Paris: École française d'Extrême-Orient.

Cœdès, G. 1941. La stèle du Práh Khan d'Ankor. Bulletin de l'École française d'Extrême-Orient 41: 255-302.

Cœdès, G. 1942. Inscriptions du Cambodge. Collection de textes et documents sur l'Indochine (Vol. II). Paris: École française d'Extrême-Orient.

Cœdès, G. 1951. Inscriptions du Cambodge. Collection de textes et documents sur l'Indochine (Vol. III). Paris: École française d'Extrême-Orient.

Cœdès, G. 1964. Inscriptions du Cambodge. Collection de textes et documents sur l'Indochine (Vol. VII). Paris: École française d'Extrême-Orient.

Cordier, P. 1906. Note additionelle sur l'inscription de la Ta Prohm. Bulletin de l'École française d'Extrême-Orient VI: 82-85.

Eade, J. C. 1995. The calendrical systems of mainland SouthEast Asia. Leiden: Brill Academic Publishers.

Ellepola, D. B. 1936. Ancient land measures of Ceylon. Transactions of the Engineering Association of Ceylon: 117-139.

Evans, D. H., R. J. Fletcher, C. Pottier, J.-B. Chevance, D. Soutif, B. S. Tan, S. Im, D. Ea, T. Tin, S. Kim, C. Cromathy, S. De Greef, K. Hanus, P. Bâty, R. Kuszinger, S. Ichita and G. Boornazian 2013. Uncovering archaeological landscapes at Angkor using lidar. Proceedings of the National Academy of Sciences of the U.S.A.: $1-6$. 
Gravelle, C. 1915. La valeur du Cambodge. Phnom Penh: Imprimerie du Protectorat.

Groslier, B. P. 1979. La cité hydraulique Angkorienne. Bulletin de l'Ecole française d'Extrême-Orient 66: 161-202.

Hultzsch, E. 1987. South Indian inscriptions. Tamil, and Sanskrit, from stone and copper-plate edicts at Mamallapuram, Kanchipuram, in the North Arcot District, and other parts of the Madras Presidency, chiefly collected in 1886-87. New Delhi: Navrang.

IRRI. Rice Knowledge Bank: Post Production Course, Module 05: Milling: Storage [Online]. Available: http://www.knowledgebank.irri.org/postproductionc ourse/module05/Lesson_04.htm [Accessed 2 June 2013].

Ismail, K. 1984. Karnataka temples: their role in socio-economic life. Delhi: Sundeep Prakashan.

Jenner, P. N. 2009. A dictionary of Angkorian Khmer. Canberra: Pacific Linguistics, Research School of Pacific and Asian Studies, Australian National University.

Lustig, E. and T. Lustig 2013. New insights into 'les interminables listes nominatives $\mathrm{d}$ ' esclaves' from numerical analyses of the personnel in Angkorian inscriptions. Aséanie 31: 55-83.

Lustig, E. J. 2009. Money doesn't make the world go round: Angkor's non-monetisation. In D. Wood (ed.) Research in Economic Anthropology. Bingley, UK: Emerald Group Publishing Ltd.

Mabbett, I. W. 1978. Kingship in Angkor. Journal of the Siam Society $66: 1-51$.

Mabbett, I. W. 1983. Some remarks on the present state of knowledge about slavery in Angkor. In A. Reid (ed.) Slavery, bondage and dependency in Southeast Asia. St Lucia, Queensland, London, New York: University of Queensland Press.

Mohapatra, D. and S. Bal 2006. Cooking quality and instrumental textural attributes of cooked rice for different milling fractions. Journal of Food Engineering 73: 253259.

Monier-Williams 2005. Cologne Digital Sanskrit Lexicon, Available: http://webapps.uni-koeln.de/tamil/

http://www.sanskrit-lexicon.unikoeln.de/monier/indexcaller.php [Accessed Nov. 2014].

Murshid, K. A. S. 1998. Food security in an Asian transitional economy: the Cambodian experience. Phnom Penh. Available: http://www.worldcat.org/title/foodsecurity-in-an-asian-transitional-economy-thecambodian-experience/oclc/41913195 [Accessed 29 September 2013]

Murthy, P. H. C. 2001. Sārngadhara Saṃhitā of Šārngadharācārya (Text, English translation, Notes, Appendix etc.). Varanasi: Chowkhamba Sanskrit Series Office.

Olivelle, P. 2013. King, governance and law in ancient India: Kauțilya's Arthaśāstra: a new annotated translation. New York: Oxford University Press.

Passmore, R., B. M. Nicol, M. Narayana Rao, G. H. Beaton and E. M. Demayer 1974. Handbook on human nutritional requirements. Geneva: World Health Organisation. Available:
http://libdoc.who.int/monograph/WHO_MONO_61.pd f [Accessed 29 September 2013].

Pou, S. 1984. Lexicographie vieux-khmère. Seksa Khmer 7: 67178.

Pou, S. 1992. Dictionnaire vieux khmer-francais-anglais. An Old Khmer-French-English Dictionary. Paris: Centre de Documentation et de Recherche sur la Civilisation Khmere.

Pou, S. 2001. Nouvelles inscriptions du Cambodge II \& III, traduites et éditées par Saveros Pou. Paris: École française d'Extrême-Orient.

Ray, P. and H. N. Gupta 1965. Caraka Saṃhitã. New Delhi: National Institute of Sciences of India.

Renou, L. and J. Filliozat 1953. L'Inde Classique. Paris Imprimerie Nationale: École Française d'Extrême-Orient.

Sedov, L. A. 1963. On the problem of the economic system in Angkor Cambodia in the IX-XII centuries. (translated by Antonia Glasse for O. W. Wolters). Narody Asii I Afriki, Istoria, Ekonomika, Kul'tura 6: 73-81.

Sharma, P. V. 1998. Caraka Saṃhitā. Varanasi: Chaukhambha Orientalia.

Sharma, R. K. and V. B. Dash 2001. Agniveśa's Caraka Samphitā: text with English translation \& critical exposition: based on Cakrapāṇi Datta's Āyurvedadīpikā. Varanasi: Chowkhamba Sanskrit Series Office.

Soutif, D. 2008. Dénombrer les biens du dieu : étude de la numération du vieux khmer (VIe-XIIe siècles śaka). Siksācakr: Journal of Cambodia Research: Revue de recherche sur le Cambodge 10: 51-80.

Soutif, D. 2009. Organisation religieuse et profane du temple khmer du VIIe au XIIIe siècle. Unpublished $\mathrm{PhD}$ dissertation, Université Sorbonne Nouvelle, Paris 3.

Stein, B. 1980. The Coromandel Brahmadeya Village. Peasant state and society in Medieval South India. Delhi: Oxford University Press.

Thion, S. 1993. Watching Cambodia : ten paths to enter the Cambodian tangle. Bangkok: White Lotus.

Vickery, M. 1985. The Reign of Sūryavarman I and royal factionalism at Angkor. Journal of Southeast Asian Studies 16: 226-244.

von Reden, S. 2007. Money in Ptolemaic Egypt: from the Macedonian Conquest to the end of the Third Century BC. Cambridge: Cambridge University Press.

Weitz-Hettelsater Engineers. 1972. Economic \& Engineering Study: rice storage, handling and marketing, for Republic of Indonesia. Sponsored by USA Agency for International Development. Missouri.

Wickremasinghe, D., de Zilva (ed.) 1912. Epigraphia Zeylanica, lithic and other inscriptions of Ceylon, London: Oxford University Press.

Wicks, R. S. 1992. Money, markets, and trade in early Southeast Asia: the development of indigenous monetary systems to AD 1400. Ithaca, N.Y.: Southeast Asia Program, Cornell University. 